\title{
MODEL PERGERAKAN TUMPAHAN MINYAK DI PERAIRAN SELAT SUNDA
}

\author{
Agus Salim 1) , Taufik Edi Sutanto 2) \\ 1) Mathematic Department, Faculty of Science and Technology UIN Jakarta \\ 2) Mathematic Department ,Faculty of Science and Technology UIN Jakarta
}

\begin{abstract}
ABSTRAK
Selat Sunda merupakan daerah yang memiliki potensi kekayaan alam yang sangat besar. Akan tetapi potensi tersebut terancam akibat tumpahan minyak yang terjadi karena adanya aktivitas transportasi dan penyimpanan minyak mentah maupun olahan di dan sekitar Selat Sunda. Sebuah penelitian pengkajian resiko ekologis tumpahan minyak dilakukan untuk mengukur seberapa besar ancaman tumpahan minyak tersebut dan menyiapkan strategi preemptive untuk meminimalisir dampak yang ditimbulkan jika tumpahan minyak berskala besar terjadi di masa depan.

Dari analisa trajectory yang dilakukan dapat disimpulkan bahwa daerah yang rawan terkena dampak tumpahan minyak adalah daerah-daerah Pantai Panimbang, Pulau Sumur, Pantai Cigeulis, Cimanggu, Selat Panaitan, Cilegon, Anyer, Penengahan, dan Jabung Sragi.

Penggunaaan data ahir trajectory menjadi acuan dalam penentuan tingkat resiko dari partikel minyak yang mengeksposure ekosistem di sekitar Selat Sunda tersebut dan terpenting adalah dapat digunakan untuk meminimalisir dampak akibat tumpahan minyak dimasa depan.
\end{abstract}

Kata Kunci: Tumpahan Minyak, Selat Sunda, Tra-jectory.

\section{PENDAHULUAN}

Pada saat terjadi sebuah bencana tumpahan minyak di laut, hal utama yang menjadi perhatian adalah, akan kemanakah minyak yang tumpah tersebut akan mengalir atau dampak apa yang akan ditimbulkannya. Mengetahui lintasan (trajectory) dari tumpahan merupakan informasi penting (crucial) untuk menentukan kebijakan lanjutan dalam menangani bencana tersebut, terutama untuk menyelamatkan lingkungan dan melakukan pembersihan. Tanpa penanganan yang tepat maka kerugian kerusakan lingkungan akan berdampak luas dan berdampak hingga jangka waktu lama.

Namun demikian untuk dapat memperkirakan pergerakan tumpahan minyak dilaut secara tepat, biasanya sangatlah sulit untuk dilakukan. Hal ini disebabkan cukup banyak proses kimiawi dan fisik yang terlibat, serta pada saat bencana terjadi informasi yang ada biasanya tidak lengkap. Untuk mengatasi hal tersebut perlu adanya suatu pemodelan trajectory sedini mungkin dengan data yang senantiasa diperbaharui (up to date) sehingga jika terjadi tumpahan minyak, penanggulangan yang efektif dan efisien dapat dilakukan dengan baik.

Sebuah pemodelan trajectory tumpahan minyak akan menganalisa berbagai akibat dan kemungkinan dari pergerakan minyak. Analisa harapan (likelihood) dari berbagai kemungkinan tersebut adalah suatu simulasi yang biasa disebut sebagai analisa trajectory. Hasil akhirnya berupa sebuah peta prediksi dari pergerakan minyak yang dapat dimanfaatkan untuk membantu penanganan bencana tumpahan minyak.

Pada saat awal-awal tumpahan minyak terjadi prediksi jalur tumpahan minyak biasanya terhambat oleh input data yang tidak lengkap. Detail tumpahan minyak (lokasi, volume, tipe minyak) seringnya masih berupa perkiraan. Lebih jauh lagi data lingkungan sekitar (angin, arus laut, dan kedalaman) terkadang tidak terhimpun atau bahkan tidak tersedia. Meskipun demikian pemodelan harus dilakukan dengan mengamati data dan mencoba untuk mengerti sifat fisik dan kimiawi yang akan mempengaruhi pergerakan minyak dan kelanjutan dari tumpahan tersebut.

Dengan pemahaman proses-proses fisik, ilmuwan dapat menganalisa situasi yang ada dan melakukan sebuah prediksi (forecast). Bila prediksi awal tidak akurat, tim model tumpahan minyak mengkaji ulang informasi yang ada (termasuk memperbaharui) dan memperbaiki prediksi. Sebuah prediksi yang tidak akurat biasanya disebabkan oleh kesalahan informasi tentang tumpahan (misal lokasi dan volume) atau ketidak tepatan informasi ingkungan 
(cuaca, angin, dan arus). Seiring berjalannya waktu prediksi akan menjadi semakin akurat, karena kondisi awal menjadi semakin tidak signifikan untuk prediksi. Sebagai ilustrasi, bagan alur analisis trajectory . Untuk mendapatkan sebuah analisa trajectory yang baik suatu faktor ketidakpastian (uncertainty) perlu untuk diikutsertakan dalam pemodelannya. Ketidak pastian tersebut dipengaruhi oleh berbagai faktor, diantaranya detail tumpahan, kondisi minyak, angin, dan arus. Lebih jelasnya Tabel 1 merupakan informasi yang diambil dari [1] yang dapat menjelaskan lebih rinci akan besarnya pengaruh ketidakpastian.

Salah satu proses oil weathering adalah Evaporasi, yaitu perubahan dari suatu cairan menjadi bentuk gas. Pada evaporasi minyak, bagian dari minyak yang lebih ringan akan terevaporasi terlebih dahulu. Pada minyak jenis tertentu, terutama minyak jenis ringan, sebagian besar akan terevaporasi. Pada suhu $15^{\circ} \mathrm{C}$ bensin akan terevaporasi sempurna setelah dua hari, $80 \%$ solar akan terevaporasi, $40 \%$ minyak light crude, $20 \%$ minyak heavy crude, dan hanya sekitar 5\% untuk tipe minyak Bunker C. Secara umum seluruh proses evaporasi yang dapat terjadi akan memakan waku kurang dari lima hari.
Proses oil weathering lainnya adalah Dispersi atau dalam hal ini pemecahan partikel minyak kecil (droplet) oleh ombak (gelombang/waves) dapat terjadi bila diameter droplet minyak relative kecil (50-70 micron). Partikel minyak yang terpecah menjadi penting, karena hal tersebut merupakan salah satu faktor yang dapat digunakan untuk meghilangkan pratikel minyak dari permukaan laut. Banyaknya partikel minyak yang terpecah berantung pada sifat minyak yang tertumpah. Diantara sifat yang mempengaruhi tersebut adalah kekentalan (viscosity) minyak dan keadaan air laut.

\section{METODOLOGI}

\section{Data dan Lokasi Penelitan}

Penelitian dilakukan di Selat Sunda, Lokasi studi trajectory berada diantara koordinat $7^{\circ} 24^{\prime}$ - 7045' lintang selatan dan $108^{\circ} 25^{\prime}$ - $108^{\circ}{ }^{\circ} 5^{\prime}$ bujur timur (Gambar 1). Waktu yang digunakan dalam studi kasus analisa trajectory dalam penelitian ini terbagi menjadi dua kasus. Kasus pertama adalah kasus ketika tumpahan terjadi pada awal tahun (Maret) dan akhir tahun (oktober).

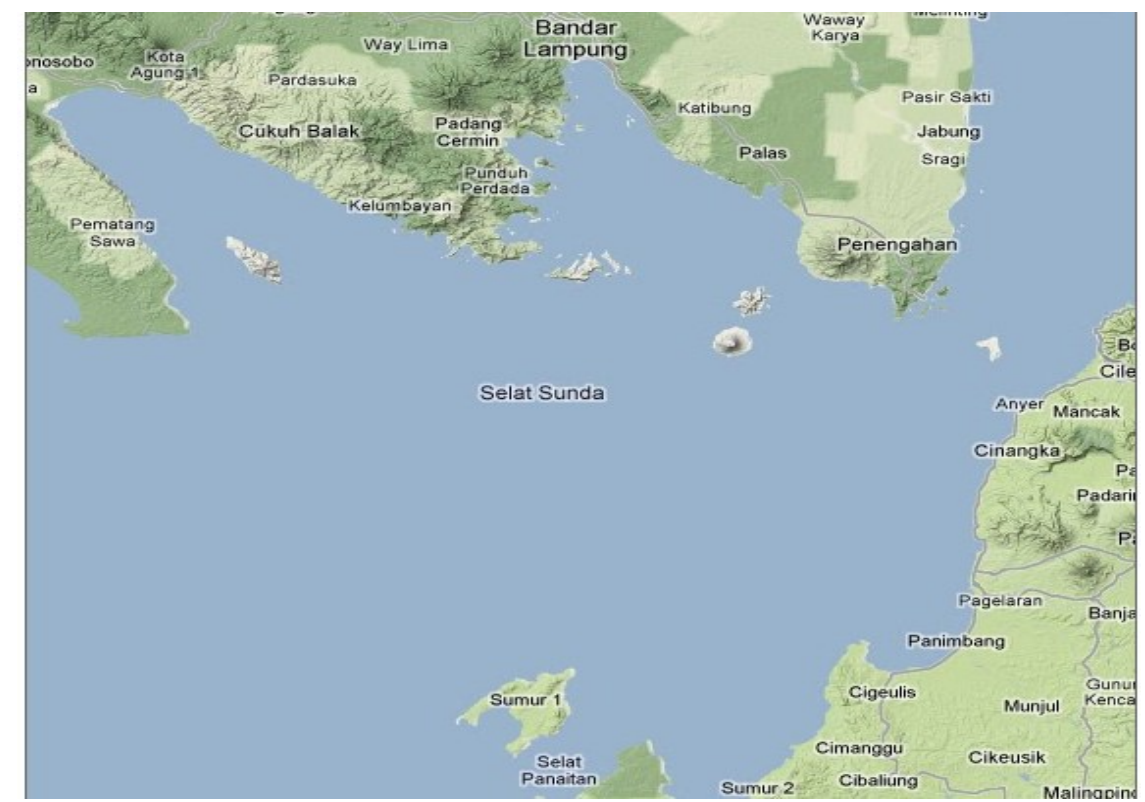

Gambar 1. Lokasi studi kasus trajectory.

Kedua kasus ini dipilih dikarenakan karakteristik arus laut sepanjang tahun menurut data satelit Ocean Surface Currents (OSCAR) berbeda pada bulan-bulan tersebut. Pada bulan Maret, arus cenderung bergerak dari arah utara ke selatan, dimana pada bulan Oktober (akhir tahun) terdapat kecenderungan dari tahun ke tahun arus akan bergerak dari samudera hindia masuk ke samudera pasifik bagian barat.

Data kecepatan arus mingguan di Selat Sunda dari tahun 1992 hingga 2011 awal (Gambar 2) 


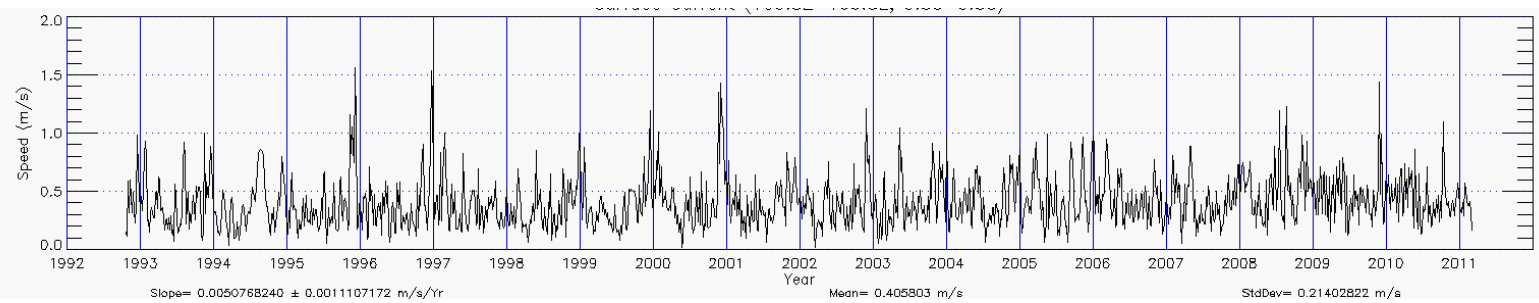

Gambar 2. Graph rangkuman data kecepatan arus di Selat Sunda (mingguan) dari tahun 19922011.

Dalam bentuk tabel, sebagian data tersebut dapat dilihat pada Lampiran 1. Dari kedua data tersebut dapat terlihat bahwa terdapat kecenderungan data kecepatan arus di Selat Sunda cenderung stasioner dengan beberapa lompatan yang biasa terjadi di awal tahun. Fakta ini dapat membantu analisa Trajectory menjadi lebih akurat, mengingat kecepatan arus yang cenderung tidak terlalu variatif (variable). Rata-rata kecepatan angin di selat sunda dari tahun 1992-2011 adalah 0.386 $\mathrm{m} / \mathrm{s}$ dengan variansi rata-rata sebesar 0.046 . Dari data tersebut dapat ditarik kesimpulan bahwa dengan kepercayaan $95 \%$ rata-rata angin pada suatu hari di Selat sunda akan terletak pada interval $0.818 \mathrm{~m} / \mathrm{s}$ sampai dengan 0.04 $\mathrm{m} / \mathrm{s}$.

Data penting lain yang diperlukan untuk analisa Trajectory adalah data angin di sekitar
Selat Sunda. Menggunakan data pada periode waktu yang sama, terlihat data dari satelit QuikSCAT memperlihatkan bahwa angin bergerak cenderung berlawanan arah dengan arus, yang mengakibatkan pergerakan minyak cenderung tidak terlalu jauh.

Rangkuman graph data kecepatan angin mingguan selama beberapa tahun (Gambar 12) menunjukkan sifat yang sama dengan arus, yaitu stasioner dengan beberapa pengecualian lompatan dibeberapa kasus waktu (Dalam bentuk tabel, sebagian data tersebut dapat dilihat pada Lampiran 1). Rata-rata kecepatan angin total dari seluruh 3750 data adalah 6.191 $\mathrm{m} / \mathrm{s}$ dan variansi sebesar 0.767. Selang kepercayaan untuk rata-rata kecepatan angin adalah antara 7.94 hingga $4.43 \mathrm{~m} / \mathrm{s}$.

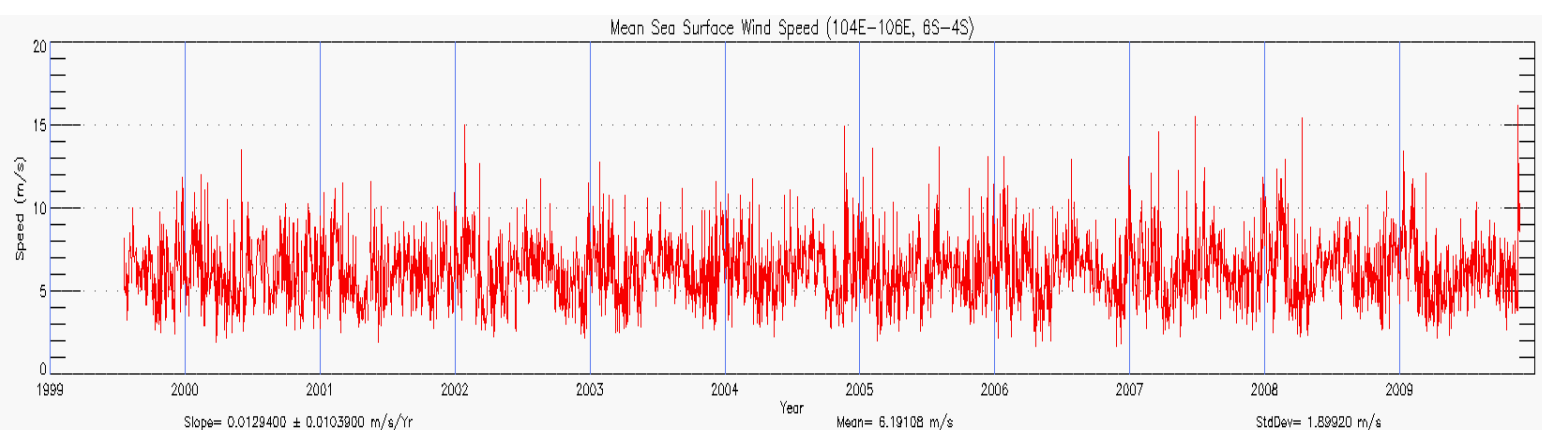

Gambar 3. Data kecepatan angin di Selat Sunda berdasarkan satelit QuickSCAT.

Data penting lain dari analisa trajectory, tentu saja data tumpahan minyak itu sendiri. Di Selat Sunda terdapat beberapa tangki kilang minyak dan distribusi minyak produk level tinggi (bensin, solar, minyak tanah, dll), namun tidak menutup kemungkinan terjadinya tumpahan produk minyak dengan kekentalan tinggi seperti oli mesin. Berikut adalah karakteristik dari ketiga tipe minyak tersebut yang akan digunakan sebagai input data analisa Trajectory.
Data terakhir yang dibutuhkan untuk melakukan analisa trajectory adalah data peta polygon Selat Sunda. Gambar 13 menunjukkan polygon dari wilayah perairan Selat Sunda, Sebagian Koordinat bujur dan lintang verteksverteks dari Polygon tersebut dapat dilihat pada Lampiran 2 yang terdiri dari 287 verteks yang membangun 2 kepulauan besar Jawa dan Sumatera, serta beberapa pulau kecil diantaranya. 


\section{Model Matematis}

Model tumpahan minyak biasanya terdiri dalam tiga tahapan model [2]. Prediksi trajectory tumpahan minyak menggunakan data actual atau percobaan. Model ini disebut juga sebagai model deterministik dan menghasilkan sebuah ekspektasi prediksi dari tumpahan minyak. Model kedua, Backtrack, menjalankan model deterministik secara runtun waktu terbalik dan biasanya digunakan untuk menentukan sumber minyak yang didapatkan di laut atau pantai. Model ini terkadang disebut juga sebagai "model misteri" dan digunakan sebagai alat untuk mengidentifikasi adanya tumpahan minyak yang dilakukan secara sengaja.

Membangun sebuah model matematika yang akan mencerminkan mdel yang sesungguhnya di dunia nyata bukanlah suatu proses yang mudah. Model yang dibuat haruslah dapat diterima karena kemiripan sifat dengan model aslinya. Oleh karena itu beberapa asumsi harus dibuat terlebih dahulu sebelum pemodelan dapat dilakukan.
Asumsi yang digunakan dalam pemodelan penyebaran tumpahan minyak yang digunakan dalam penelitian ini adalah:

1) Penyebaran searah dengan arah arus air.

2) Ukuran maksimum tumpahan (droplet) adalah ukuran partikel minyak sedemikian sehingga ia tidak akan mengambang.

3) Arus diasumsikan konstan dan tenang (placid).

4) Efek suhu, angin, dan tekanan diabaikan.

Menggunakan asumsi-asumsi tersebut diharapkan model yang terbentuk dapat mewakili penyebaran minyak yang sesungguhnya.

Model tersebut akan dikombinasikan dengan model system persamaan differensial hidrodinamika fluida seperti yang dikemukakan di [3], yaitu:

$$
\begin{aligned}
\frac{\delta u}{\delta t}+u \frac{\delta u}{\delta x}+v \frac{\delta u}{\delta y}+g \frac{\delta w}{\delta x} & =-g \frac{u \sqrt{u^{2}+v^{2}}}{(w+h) c^{2}}+f v \\
\frac{\delta v}{\delta t}+u \frac{\delta v}{\delta x}+v \frac{\delta v}{\delta y}+g \frac{\delta w}{\delta y} & =-g \frac{v \sqrt{u^{2}+v^{2}}}{(w+h) c^{2}}+f u \\
\frac{\delta w}{\delta t}+\frac{\delta[(w+h) u]}{\delta x}+\frac{\delta[(w+h) v]}{\delta y} & =0
\end{aligned}
$$

$u, v$ adalah kecepatan arus terhadap komponen timur dan utara (bujur dan lintang), $w$ adalah kedalaman laut, $t$ waktu, $h$ kedalaman dimana air diasumsikan tidak dipengaruhi arus atas, dan $c$ adalah suatu ketetapan koefisien tertentu.
Pada permasalahan nyata tentu saja terdapat sebuah batasan [pantai] yang merupakan sebuah Boundary Condition (BC) bagi gelombang. BC yang dipergunakan dalam pemodelan penelitian ini menggunakan formula

$$
\zeta_{(i, j)}(k)=H_{(i, j)} \cos \left(\sigma k-g_{(i, j)}\right), \quad k=0,1, \ldots, N-1
$$

dimana $H$ adalah amplitudo, $g$ jeda fase (phase lag), $N$ banyaknya langkah dalam satu periode gelombang, dan $\sigma$ adalah frekuensi angular dari komponen gelombang.

Dari model hidrodinamik yang telah ditetapkan diatas, kemudian model gelombang laut dikembangkan dengan memperhatikan gravitasi permukaan gelombang akibat angin, atau yang biasa disebut sebagai irregular long crested (ILC). ILC ditambahkan dengan cara menambahkan sejumlah gelombang regular long crested (RLC) dengan amplitudo dan panjang gelombang yang berbeda-beda, sehingga pada saat tertentu tinggi gelombang dimodelkan sebagai berikut:

$$
\zeta=H_{\text {tide }}+\sum_{t=1}^{n} \zeta_{a t} \cos \left(k_{t}(x \sin \theta+y \cos \theta)+\omega_{t} t+\varphi_{t}\right)
$$


$H_{\text {tide }}$ adalah tinggi gelombang, $g$ adalah percepatan gravitasi, $\theta$ arah propagasi gelombang, $\theta \in[0,2 \pi], t$ adalah waktu, $\varphi_{t}$ adalah sudut fase, $k_{t}$ adalah gelombang yang didapat dari persamaan dispersi.

Model untuk difusi minyak terdiri dari tiga bagian: difusi gravitasi, difusi glutinosity, dan difusi tekanan permukaan. Ketiga bagian model tersebut diberikan oleh persamaan berikut:

$$
\begin{aligned}
& r(t)=K_{1}\left(\Delta g V t^{2}\right)^{\frac{1}{4}} \\
& r(t)=K_{2}\left(\frac{\Delta g V t^{\frac{2}{3}}}{v^{\frac{1}{2}}}\right)^{\frac{1}{6}} \\
& r(t)=K_{3}\left(\frac{\sigma^{2} t^{3}}{\rho^{2} v}\right)^{\frac{1}{4}}
\end{aligned}
$$

Dimana $\Delta g=\left(\rho-\rho_{0}\right) * g / \rho, \rho_{0}$ dan $\rho$ adalah adalah kepadatan minyak dan air. $r(t)$ adalah skala difusi minyak, $\sigma=\delta_{w a}-\delta_{a o}-\delta_{o w}$, dimana $\delta_{w a}, \delta_{a o}$, dan $\delta_{o w}$ adalah tekanan permukaan antara air dengan udara, minyak dengan udara, dan minyak dengan air. $\mathrm{v}$ adalah koefisien kekentalan kinematik air, $t$ menyatakan waktu, V sebagai volume minyak, dan k1, k2, dan k3 adalah koefisien percobaan dengan nilai tertentu (biasanya antara 1-1,5).

Pemodelan diatas memperhitungkan setiap satuan tumpahan (droplet) dari tumpahan minyak yang terjadi. Hal tersebut mengakibatkan penyelesaian model diatas menjadi sangat kompleks dan membutuhkan komputasi yang sangat tinggi. Selanjutnya hasil simulasi tersebut dilakukan dengan bantuan software aplikasi Gnome dan Spill Tool untuk melihat hasil simulasi terbaik.

\section{Analisis Trajectory Gnome}

Setelah data kelautan, geografis, dan karakteristik minyak telah didapatkan selanjutnya analisa tajectory dilakukan menurut standar internasional NOAA (National Oceanic and Atmospheric Administration). Badan khusus internasional penanganan bencana di laut Emergency Response Division (ERD) , dibawah NOAA mendesain suatu software khusus untuk melakukan analisa trajectori tumpahan minyak yang diberi nama GNOME (General NOAA Operational Modeling Environment). Perangkat lunak Gnome akan digunakan untuk menganalisa simulasi trajectory dari tumpahan minyak di Selat Sunda.

Gnome (Gambar 4) memiliki dua fungsi utama, standar dan diagnostic mode. Pada mode standar digunakan loc file, yang berupa informasi peta polygon, arus, angin, karakteristik minyak, kedalaman laut, dan data lainnya. Pada mode tersebut pengguna hanya memvariasikan berbagai parameter tambahan seperti jumlah tumpahan dan pengaruh tambahan untuk melihat dampaknya terhadap perubahan trajectory minyak. Walaupun menggunakan mode standar sangatlah mudah, namun loc file yang tersedia sangat terbatas, yang sebagian besar adalah loc file laut disekitar Amerika.

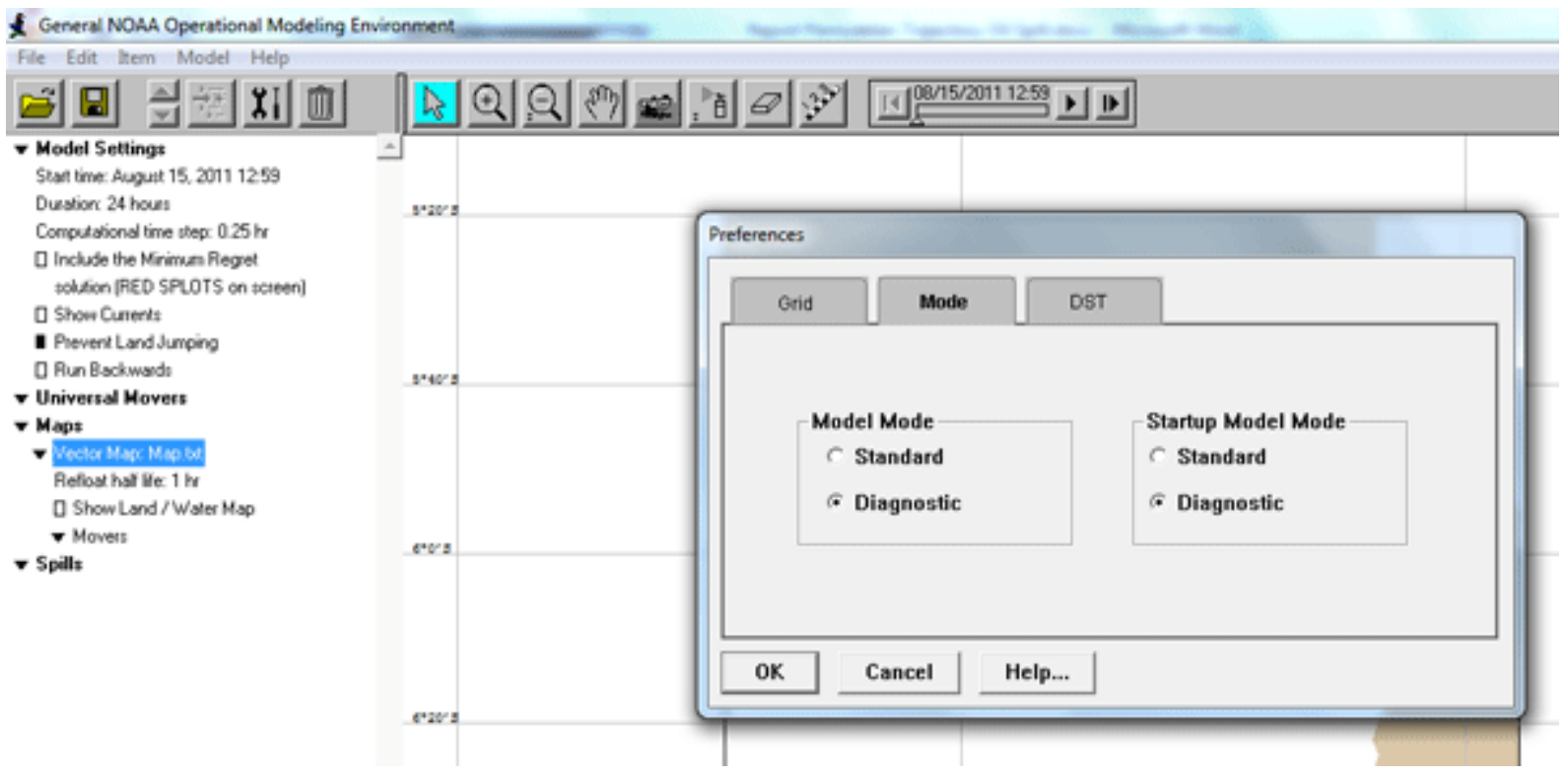

Gambar 4. Perangkat lunak Analisa Trajectory ERD-NOAA Gnome. 
Dalam penelitian ini digunakan mode diagnostic, dikarenakan loc file untuk Selat Sunda tidak tersedia. Untuk mengawali penggunaan mode diagnostic, pertama-tama diperlukan peta polygon dari daerah yang akan diteliti. Peta Polygon tersebut menggunakan format BNA (Atlas Boundary File). BNA diawali dengan tiga parameter awal, sebagai contoh "234","1",33 yang berarti feature 234, polygon daratan, lalu terdiri dari 33 verteks. Setelah baris ini diikuti dengan 33 vertex lokasi pulau yang akan diteliti.

Parameter berikutnya dalam peta polygon adalah Batas Peta, format batas peta adalah "Map Bounds","1",7 yang berarti terdapat 7 verteks yang akan membatasi perhitungan pergerakan droplet minyak. Daerah yang dapat atau mungkin terjadi tumpahan minyak dinyatakan dengan "SpillableArea", "1", 15. Sama seperti sebelumnya 15 menyatakan daerah tersebut dikarakterisasi oleh 15 verteks pembatas daerah tumpahan.

Data arus laut di Gnome menggunakan format CATS - Finite Element - Velocities on Triangles, Steady State. Gambar 15 memperlihatkan salah satu contoh penggunaan segitiga pada finite element dalam data arus Gnome. Arus yang dapat digunakan tidak hanya arus permukaan, namun juga kecepatan arus pada berbagai kedalaman.

Data angin dalam diagnostic mode Gnome menggunakan format WND. Dalam format ini arah, besaran, dan waktu akan kecepatan angin diberikan dalam bentuk seperti yang nampak pada Gambar 5.

$\begin{array}{lcccccc}\text { Day, } & \text { Month, } & \text { Year, } & \text { Hour, } & \text { Min., } & \text { Speed, } & \text { Direction } \\ 8, & 4, & 99, & 01, & 00, & 0, & \text { S } \\ 8, & 4, & 99, & 05, & 00, & 10, & 5 \\ 8, & 4, & 99, & 09, & 00, & 10, & 5 \\ 8, & 4, & 99, & 11, & 00, & 10, & 5 \\ 8, & 4, & 99, & 15, & 00, & 10, & S W\end{array}$

Gambar 5. Format WND untuk data angin laut pada Gnome.

\section{HASIL DAN PEMBAHASAN}

\section{Hasil Simulasi \& Analisa Ketidakpastian}

Simulasi tumpahan minyak jenis medium crude oil sebesar 3000 barrel dilakukan dengan tumpahan berawal dari jalur distribusi minyak.
Simulasi memanfaatkan data angin dan arus seperti yang sudah dijabarkan sebelumnya dan menggunakan data musim awal tahun, dalam hal ini bulan Maret. Setelah menjalankan simulasi selama beberapa hari, didapatkan hasil seperti pada Gambar 6.

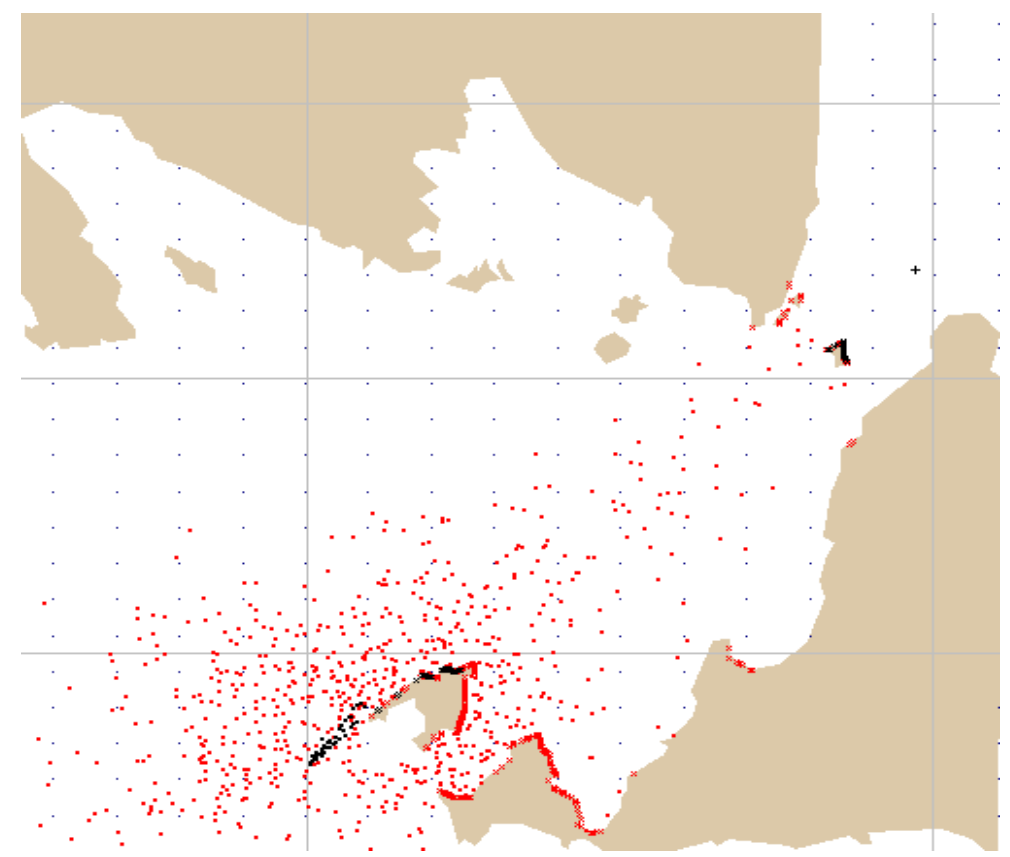

Gambar 6. Simulasi pergerakan Minyak di Selat Sunda setelah 10 hari. 
Dari simulasi tersebut dapat disimpulkan bahwa daerah yang terkena dampak, bila terjadi tumpahan pada awal tahun adalah sumatera bagian selatan (Penengahan), Pantai Cigeulis, Pulau Sumur, dan Selat Panaitan, dengan dampak terbesar terjadi di Pulau Sumur 1.
Simulasi berikutnya kemudian dilakukan dengan menggunakan data musiman untuk akhir tahun. Jumlah tumpahan dan jenis minyak sama seperti simulasi sebelumnya. Hasil simulasi dalam jangka waktu empat hari setelah tumpahan diberikan dalam Gambar 7.

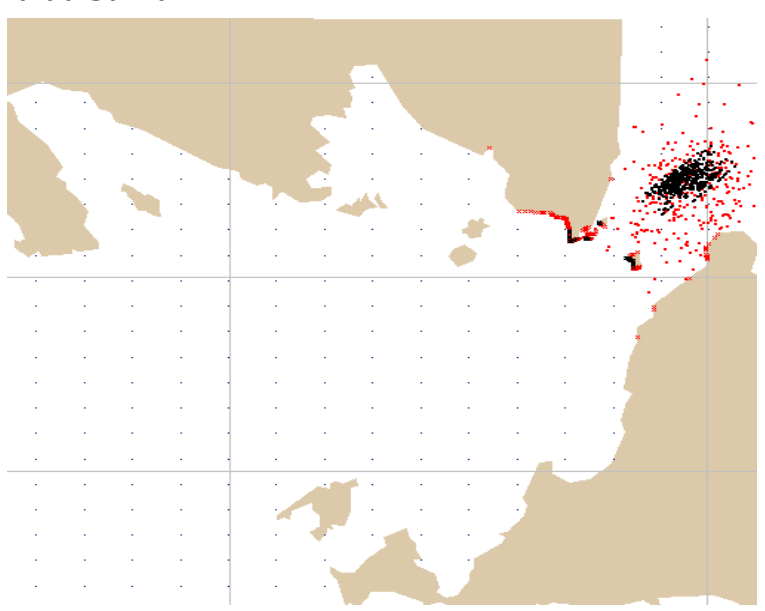

Gambar 7. Simulasi jika tumpahan minyak terjadi pada akhir tahun.

Hasil simulasi selama empat hari untuk data simulasi akhir tahun (Gambar 18) menunjukkan bahwa Selat Sunda minimal terkena dampak tumpahan minyak. Dalam minggu pertama daerah di sekitar Bojonegara, Anyer, dan Penengahan terkena dampak yang cukup besar. Dalam waktu lebih dari dua minggu jika jumlah tumpahan cukup banyak, maka ada kemungkinan pencemaran akan menjangkau Kalimantan dan negara tetangga
Singapura.Permasalahan berikutnya yang cukup penting untuk dianalisa adalah seberapa besar dampak pencemaran pada lokasi-lokasi yang telah disebutkan diatas. Untuk menganalisa tingkat pencemaran tersebut digunakan ROC (Response Options Calculator). Dengan menggunakan parameter yang sama dengan trajectory Gnome, ROC dapat menghitung berapa bagian minyak yang telah melalui proses Oil Weathring (evaporasi, dispersi, dan residue) (Gambar 8).

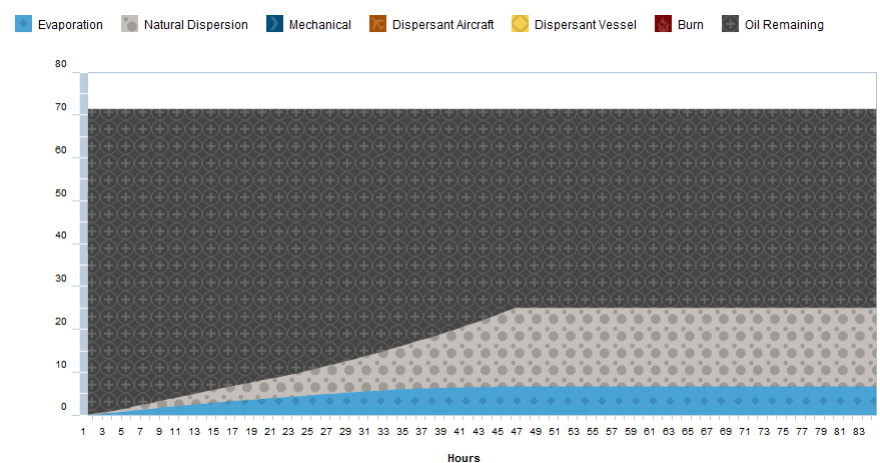

Gambar 8. Hasil perhitungan presentasi kadar pencemaran di Selat Sunda.

\section{KESIMPULAN DAN SARAN}

Dari analisa trajectory yang dilakukan dapat disimpulkan bahwa daerah yang rawan terkena dampak tumpahan minyak adalah daerah-daerah sebagai berikut (Gambar 20)
Pantai Panimbang, Pulau Sumur, Pantai Cigeulis, Cimanggu, Selat Panaitan, Cilegon, Anyer, Penengahan, Jabung Sragi. Saran dari penelitian ini adalah penelitian ini masih dalam skala laboratorium (simulasi). Akan lebih lengkap bila 
dilakukan proses validasi terhadap hasil simulasi pergerakan partikel minyak di akhir pengamatan dengan waktu,bukan dan kondisi sebenarnya di lapang. Sehingga akan dapat terlihat validitas dan keakuratan model yang dibangun. Penelitian ke depan adalah melakukan proses validasi hasil akhir tersebut pada kondisi,iklim sebenarnya.

\section{Bibliography}

[1] A. Jimoh and M. Alhassan, "Modelling and simulation of crude oil dispersion," Leonardo Electron. J. Pract. Technol., vol. 5, no. 8, pp. 1728, 2006.
[2] M. L. Spaulding, V. S. Kolluru, E. Anderson, and E. Howlett, "Application of three-dimensional oil spill model (WOSM/OILMAP) to Hindcast the $<$ i $>$ Braer $<$ i $>$ spill," Spill Sci. Technol. Bull., vol. 1, no. 1, pp. 23-35, 1994.

[3] F. Yu and Y. Yin, "Oil spill visualization based on the numeric simulation of tidal current," in Proceedings of The 7th ACM SIGGRAPH International Conference on Virtual-Reality Continuum and Its Applications in Industry, 2008, p. 28. 


\section{LAMPIRAN-LAMPIRAN}

\section{Lampiran 1: Data Kecepatan Angin \& Arus di Selat Sunda Selama Beberapa Tahun}

$\begin{array}{llllll}\text { Tanggal } & \text { ReRata Angin } & \text { Variansi } & \text { Date } & \text { ReRata Arus } & \text { Variansi } \\ 7 / 29 / 1999 & 4.328433 & 1.7936478 & 12 / 11 / 1992 & 0.526463 & 0.369623 \\ 7 / 30 / 1999 & 5.2825038 & 1.8516024 & 12 / 16 / 1992 & 1.00257 & 0.984601 \\ 7 / 31 / 1999 & 5.8838556 & 0.95648555 & 12 / 21 / 1992 & 0.635397 & 0.669616 \\ 8 / 1 / 1999 & 5.5123405 & 1.6233164 & 12 / 26 / 1992 & 0.460883 & 0.482043 \\ 8 / 2 / 1999 & 7.4288562 & 1.0785921 & 1 / 1 / 1993 & 0.387529 & 0.33567 \\ 8 / 3 / 1999 & 7.3761565 & 1.8431835 & 1 / 6 / 1993 & 0.476694 & 0.454172 \\ 8 / 4 / 1999 & 8.485566 & 1.1580675 & 1 / 11 / 1993 & 0.359789 & 0.333094 \\ 8 / 5 / 1999 & 7.839028 & 0.99348769 & 1 / 16 / 1993 & 0.534405 & 0.514174 \\ 8 / 6 / 1999 & 7.5892326 & 1.4727978 & 1 / 21 / 1993 & 0.832444 & 0.818649 \\ 8 / 7 / 1999 & 7.0998994 & 1.7550339 & 1 / 26 / 1993 & 0.615157 & 0.932113 \\ 8 / 8 / 1999 & 6.9291045 & 1.1770411 & 1 / 31 / 1993 & 0.664582 & 0.796478 \\ 8 / 9 / 1999 & 5.4590789 & 1.4110885 & 2 / 5 / 1993 & 0.19502 & 0.244655 \\ 8 / 10 / 1999 & 6.7429213 & 1.3620754 & 2 / 10 / 1993 & 0.309104 & 0.251402 \\ 8 / 11 / 1999 & 7.3185649 & 1.6466063 & 2 / 15 / 1993 & 0.163413 & 0.150595 \\ 8 / 12 / 1999 & 10.005049 & 1.3535395 & 2 / 20 / 1993 & 0.297904 & 0.307282 \\ 8 / 13 / 1999 & 8.0106097 & 0.47421375 & 2 / 25 / 1993 & 0.458922 & 0.360722 \\ \ldots & & \ldots & \ldots & \ldots & \ldots \\ 3 / 6 / 2003 & 6.3151514 & 3.6660507 & 1 / 1 / 2011 & 0.404298 & 0.369638 \\ 3 / 7 / 2003 & 8.1872091 & 3.1166491 & 1 / 6 / 2011 & 0.307276 & 0.333587 \\ 3 / 8 / 2003 & 6.1029508 & 2.2004977 & 1 / 11 / 2011 & 0.315274 & 0.319965 \\ 3 / 9 / 2003 & 4.3183583 & 0.93758907 & 1 / 16 / 2011 & 0.334781 & 0.401904 \\ 3 / 10 / 2003 & 3.5829664 & 2.3982565 & 1 / 21 / 2011 & 0.229897 & 0.285396 \\ 3 / 11 / 2003 & 2.4757332 & 1.3811929 & 1 / 26 / 2011 & 0.59927 & 0.566984 \\ 3 / 12 / 2003 & 5.6816771 & 3.7906258 & 1 / 31 / 2011 & 0.583347 & 0.519379 \\ 3 / 13 / 2003 & 3.9427958 & 1.1597723 & 2 / 5 / 2011 & 0.325766 & 0.421876 \\ 3 / 14 / 2003 & 5.6493751 & 1.3974251 & 2 / 10 / 2011 & 0.274698 & 0.375643 \\ 3 / 15 / 2003 & 5.2963544 & 3.9728989 & 2 / 15 / 2011 & 0.359002 & 0.37683 \\ 3 / 16 / 2003 & 3.1243345 & 0.63200567 & 2 / 20 / 2011 & 0.385987 & 0.412617 \\ 3 / 17 / 2003 & 2.5974114 & 1.3625091 & 2 / 25 / 2011 & 0.319986 & 0.323262 \\ 3 / 18 / 2003 & 8.294951 & 3.0138123 & 3 / 2 / 2011 & 0.136407 & 0.163611\end{array}$

\section{Lampiran 2:}

Format Peta Polygon Analisis Trajectory

$104.685974,-5.932972$ $104.669495,-5.924777$

"2068","1",26

$104.529419,-5.826419$

$104.529419,-5.544913$ $104.669495,-5.938436$ $104.606323,-5.9439$

104.545898,-5.555848 $104.60083,-5.93024$

$104.559631,-5.599585$

104.61731,-5.659719

$104.650269,-5.717113$

$104.636536,-5.741708$

$104.655762,-5.758105$

$104.655762,-5.771769$

$104.677734,-5.793629$

$104.702454,-5.831884$

$104.694214,-5.867403$

$104.724426,-5.911117$

104.724426,-5.927508 